\title{
Passiflora incarnata treatment during gestation and lactation: toxicological and antioxidant evaluation in wistar dams
}

\author{
Karine Maria Boll ${ }^{1}$, Chiara Cristina Bortolasci ${ }^{2}$, Tiago Zaminelli ${ }^{4}$, Luiz Fernando Veríssimo ${ }^{4}$, André \\ Demambre Bacchi ${ }^{4}$, Luciana Higachi ${ }^{2}$, Décio Sabbatini Barbosa ${ }^{3}$, Estefânia Gastaldello Moreira ${ }^{4, *}$
}

\begin{abstract}
${ }^{1}$ Pharmacy Division, University Hospital, State University of Londrina, UEL, Londrina, PR, Brazil, ${ }^{2}$ Research Laboratory, Health Sciences Center, State University of Londrina, UEL, Londrina, PR, Brazil, ${ }^{3}$ Department of Pathology, Clinical and Toxicological Analyses, Health Sciences Center, State University of Londrina, UEL, Londrina, PR, Brazil, ${ }^{4}$ Department of Physiological Sciences, Biological Sciences Center, State University of Londrina, UEL, Londrina, PR, Brazil
\end{abstract}

\begin{abstract}
Passiflora incarnata is marketed in many countries as a phytomedicine. Even though the directions of most marketed phytomedicines recommend them to be used under medical supervision, reproductive and developmental studies are sparse and not mandatory for regulatory purposes. In this study, a reproductive toxicity evaluation of $P$. incarnata was conducted in Wistar rats gavaged $(30 \mathrm{or} 300 \mathrm{mg} / \mathrm{kg}$ ) during pregnancy and lactation. Moreover, considering that antioxidant properties have been attributed to flavonoids present in the genus Passiflora, it was also evaluated the antioxidant/pro-oxidant balance in the plasma of these dams and the antioxidant potential in an in vitro test. $P$. incarnata treatment did not influence dams' body weight as well as reproductive (gestation length, post-implantation loss, litter size, litter weight) and hepatic (albumin, AST, ALT, GGT) parameters. The antioxidant property of $P$. incarnata was evidenced both in vivo (increase in the total antioxidant plasmatic potential) and in vitro (decrease in neutrophil-induced respiratory burst). The results from the present study indicate that under the experimental conditions evaluated, $P$. incarnata treatment during gestation and lactation presented antioxidant activity in the absence of maternal reproductive toxicity.
\end{abstract}

Uniterms: Phytomedicines/evaluation. Passiflora incarnata/use in pregnancy. Passiflora incarnata/ use in lactation. Passiflora incarnata/reproductive toxicity/experimental study. Pregnancy/use of phytomedicines. Lactation/use of phytomedicines. Oxidative stress.

Passiflora incarnata é comercializada em muitos países como fitoterápico. Embora a bula da maioria dos fitoterápicos recomende que eles sejam usados sob supervisão médica, estudos sobre a toxicidade reprodutiva e do desenvolvimento desses produtos são raros e não obrigatórios para fins regulatórios. Neste estudo, realizamos uma avaliação da toxicidade reprodutiva da $P$. incarnata, administrada a ratas Wistar (30 ou $300 \mathrm{mg} / \mathrm{kg}$, gavagem) durante a gestação e a lactação. Além disso, considerando as propriedades antioxidantes que têm sido atribuídas aos flavonoides presentes no gênero Passiflora, também avaliou-se o equilíbrio antioxidante/pró-oxidante no plasma destas fêmeas e conduziu-se um teste in vitro para avaliar o potencial antioxidante. $\mathrm{O}$ tratamento com $P$. incarnata não influenciou o peso corporal das fêmeas, bem como indicadores de toxicidade reprodutiva (perdas pós-implantação, número de filhotes vivos e peso da ninhada) e os parâmetros de função hepática (albumina, AST, ALT, GGT). A propriedade antioxidante da $P$. incarnata foi evidenciada tanto in vivo (aumento do potencial antioxidante total plasmático) quanto in vitro (diminuição do burst respiratório em neutrófilos). Os resultados deste estudo indicam que, nas condições experimentais avaliadas, o tratamento com $P$. incarnata durante a gestação e lactação apresentou efeito antioxidante, na ausência de toxicidade reprodutiva materna.

Unitermos: Fitoterápicos/avaliação. Passiflora incarnata/uso na gestação. Passiflora incarnata/uso na amamentação. Passiflora incarnata/toxicidade reprodutiva/estudo experimental. Gestação/uso de fitoterápicos. Lactação/uso de fitoterápicos. Estresse oxidativo.

\footnotetext{
*Correspondence: E. G. Moreira. Departamento de Ciências Fisiológicas, Centro de Ciências Biológicas, Universidade Estadual de Londrina, Campus Universitário, 86051-980 - Londrina-PR, Brasil. E-mail: egmoreira@uel.br
} 


\section{INTRODUCTION}

Herbal medicine products (HMP) have been used worldwide (Yunes, Calixto, 2001; Buttar, Jones, 2003; Koren et al., 2008). The belief on the safety of natural products (Buttar, Jones, 2003) makes HMPs appealing for some populational groups including children, pregnant women and the elderly.

Passiflora incarnata is marketed in many countries as an anxiolytic and sedative phytomedicine (Soulimani et al., 1997; Zanoli, Avallone, Baraldi, 2000) and its mechanism of action involves potentiation of the GABAergic system (Zanoli, Avallone, Baraldi, 2000; Grundmann et al., 2008). As observed for many HMP used by the population, information regarding the safety of $P$. incarnata use during pregnancy and/or lactation is sparse (Veríssimo et al., 2011). To the best of our knowledge, only one study suggested, in vitro, an uterotonic action of this plant (Ruggy, Smith, 1940). Based on this study, the labels of $P$. incarnata-based phytomedicines marketed in Brazil indicate that its use during pregnancy and/or breastfeeding needs physician or dentist supervision (Brasil, 2008). However, advising without scientific support certainly is not an easy task for these professionals.

This study was designed to investigate if $P$. incarnata induces maternal toxicity when administered to Wistar rats during pregnancy and lactation. Moreover, considering that antioxidant properties have been attributed to flavonoids present in the genus Passiflora (Rudnicki et al., 2007; Masteikova et al., 2008), it was also evaluated the antioxidant/pro-oxidant balance in the plasma of these dams as well as $P$. incarnata antioxidant potential through an in vitro test.

\section{MATERIAL AND METHODS}

\section{Animals and treatment}

Male and female wistar rats (75-90 days) from the colony of the State University of Londrina (UEL) were mated ( 2 or 3 females and 1 male per cage) overnight and gestational day (GD) 0 was considered if there were sperm and estrus phase cells in vaginal smears.

Pregnant rats were housed singly and randomly divided into control- or P. incarnata-treated dams. Control dams (Con: 15 dams) were gavaged daily with tap water whereas $P$. incarnata were gavaged with 30 (P30: 17 dams) or 300 (P300: 14 dams) mg/kg. Treatment lasted from GD 0 to lactational day (LD) 21 and doses were daily adjusted according to weight. A HMP marketed in Brazil (Passiene $^{\mathrm{TM}}$, Herbarium Laboratories) was employed as the source of $P$. incarnata. This syrup is standardized in $0.19 \%$ of vitexin. In humans, the dose of $20-30 \mathrm{mg} / \mathrm{kg} / \mathrm{day}$ is usually recommended.

All animals had free access to water and regular lab chow (Nuvital $\left.{ }^{\mathrm{TM}}\right)$. They were maintained in the vivarium of the Department of Physiological Sciences at $21 \pm 2{ }^{\circ} \mathrm{C}$ on a $12: 12 \mathrm{~h}$ light-dark cycle (on at 0700 ). All animal procedures were approved by the UEL Ethics Committee for Animal Research (CEEA 16/2010).

\section{Maternal toxicity and reproductive performance of dams}

Maternal body weight was measured daily during gestation and lactation. Furthermore, the corrected maternal body weight gain was estimated subtracting the weight on GD 0 from the weight on LD 0 . On LD 0 , the number of pups in each litter was determined as well as the litter weight. On LD 21, dams were submitted to an open-field in order to evaluate general activity (Bacchi et al., 2013). They were euthanized with diethyl ether and their livers were dissected and weighed. The uterine horns were also dissected and the numbers of implantation sites were counted to determine the rate of postimplantation loss [(number of implantations-number of live fetuses/ number of implantations)x 100]. Blood was collected through cardiac puncture and centrifuged at $1000 \mathrm{~g}$ for 15 minutes. Plasma was aliquoted and stored at $-70{ }^{\circ} \mathrm{C}$ for subsequent laboratory testing. Hepatic function was evaluated through the determination of gamma-glutamyl transferase (GGT), aspartate aminotransferase (AST), alanine aminotransferase (ALT), albumin and total proteins. GGT, ALT and AST were analyzed using UVkinetic methods in an automated biochemical system (Dimension ${ }^{\circledR}$ RXL, Deerfield, IL, USA). Albumin and total protein were measured through the use of colorimetric commercial kits (Ebram ${ }^{\mathrm{TM}}$, Brazil).

\section{Plasmatic antioxidant/pro-oxidant balance}

Total serum antioxidant potential (TRAP) was determined by chemiluminescence using an adaptation from the method described by Repetto et al. (1996). This experiment was conducted in a Beckman $\beta$ counter, model LS 6000 (Fullerton, CA, USA) in a non-coincident counting mode for 25 minutes and with a response range between 300 and $620 \mathrm{~nm}$. The system was calibrated with vitamin $\mathrm{E}$ analogue (Trolox). A comparison of the induction time after the addition of known concentrations of Trolox and plasma allows obtaining TRAP values of Trolox equivalents. 
Pro-oxidant markers evaluated in this work were lipid hydroperoxides, malondialdehyde (MDA), products of advanced protein oxidation (AOPP) and nitric oxide (NO).

Lipid hydroperoxides were measured by spectrophotometry (FOX) using an adaptation of the technique described by Jiang, Woollard, Wolff (1991). The method is based on the oxidation of ferrous to ferric ions by peroxide under acidic conditions, which reacts with the indicator dye (xylenol orange) and produces a colored complex. The system was calibrated with a standard solution of 1,1,3,3-tetraethoxyproprane. The reading was performed in a spectrophotometer (Helios $\alpha$ ThermoSpectronic ${ }^{\mathrm{TM}}$, Waltham, MA, USA) at a wavelength of $560 \mathrm{~nm}$ and the results are expressed in $\mathrm{mM}$.

MDA, which results from the decomposition of hydroperoxides, was quantified by high performance liquid chromatography using an adaptation of the technique described by Bastos et al. (2012). Results are expressed in $\mathrm{nM} / \mathrm{mg}$ of protein.

AOPP was quantified by the method described by Witko-Sarsat et al. (1998). The method is based on the reaction of oxidized proteins with potassium iodide in acid conditions. The calibration curve was obtained from a stock solution of $1 \mathrm{mM}$ chloramine and the absorbance of the reaction was determined spectrophotometrically (Helios $\alpha$ ThermoSpectronic ${ }^{\circledR}$, Waltham, MA, USA) at $340 \mathrm{~nm}$. AOPP concentrations are expressed in $\mu \mathrm{M} / \mathrm{L}$ equivalent of chloramine.

NO levels were assessed indirectly by determining the plasma concentration of nitrite, using an adaptation of the technique described by Navarro-Gonzalez, GarciaBenayas and Arenas (1998). The quantification of nitric oxide was made in a microplate reader (Biochrom ASYS Expert Plus ${ }^{\mathrm{TM}}$, Holliston, MA, USA) at a wavelength of $550 \mathrm{~nm}$. The results are expressed in $\mu \mathrm{M} / \mathrm{L}$.

\section{In vitro evaluation of the antioxidant activity of $\boldsymbol{P}$. incarnata}

The reactive oxygen species (ROS) production by neutrophils (respiratory burst) was evaluted by chemiluminescence according to an adaptation of the method described by Freitas et al. (2008) and Huber, Krötz-Fahning, Hock (2006) in a multiplate reader (Victor $\mathrm{X} 3$, Perkin Elmer, USA). Human neutrophils were isolated from whole blood through gradient density centrifugation. Neutrophil burst was induced by phorbol myristate acetate (PMA) in the presence of 5 or $10 \mu \mathrm{L}$ of $P$. incarnata syrup $(75 \mathrm{mg} / \mathrm{mL}$ ) or vehicle (base syrup). The detection probe was luminol. Kinetic readings were initiated immediately after cell stimulation and measured each other minute for
60 minutes. Effects are expressed as chemiluminescence arbitrary units (cpm). For each experimental group, 8-10 replicates were conducted. For statistical analysis, the peak value of each curve was used, independently of the time it occurred.

\section{Statistical analysis}

Initially, an exploratory analysis was conducted to evaluate normal distribution (Shapiro-Wilk test) and homogeneity of variance (Levene test) of each variable. For variables that presented normal distribution and homogeneity of variance, parametric analysis were conducted. Due to the high number of dams employed in this study, they could not be treated all at once and our sample is composed from animals belonging to two different cohorts. Because of this, cohort was added as a factor in the statistical analysis. The parametric statistical tests employed in this study were:

- Two-way ANOVA (factors: cohort, treatment) complemented with Bonferroni: corrected maternal body weight gain, litter size, litter weight, postimplantation loss, liver weight, open-field behaviors (ambulation, rearing), biochemical parameters (except AST);

- $\quad$ Two-way Repeated Measures ANOVA (RMANOVA) complemented with Bonferroni: weight gain of dams;

- $\quad$ Two-way ANCOVA complemented with Bonferroni: liver weight (weight on LD 21 was the covariate). Grooming behavior evaluated in the open-field, AST and data from respiratory burst did not present normal distribution and/or homogeneity of variance and were analyzed through the non-parametric test of KruskalWallis complemented with Dunn. Differences were considered significant if $\mathrm{p}<0.05$.

\section{RESULTS}

\section{Maternal toxicity and reproductive performance of dams}

Gestation length was not influenced by Passiflora treatment and no clinical signs of toxicity were observed during the daily treatment. RMANOVA indicated an effect of the day on dams' weight $[\mathrm{F}(3,111)=651.9, \mathrm{p}<0.0001]$ reflecting the fluctuations that occur during pregnancy and lactation (data not shown). P. incarnata treatment did not influence ( $p>0.05)$ weight gain as well as the corrected weight gain of dams during gestation (weight in LD 0 weight in GD 0). Means and SEM for the corrected weight 
gain were Con=32.7 $\pm 4.2(\mathrm{n}=15) ; \mathrm{P} 30=25.9 \pm 3.2(\mathrm{n}=17)$; $\mathrm{P} 300=22.6 \pm 2.8(\mathrm{n}=14)$. Two-way ANOVA showed that $P$. incarnata treatment did not influence $(\mathrm{p}>0.05)$ the number of uterine implantation sites, post-implantation loss, number of pups per litter and weight of pups at birth (Table I). Dead pups at birth were observed in 2 Con litters and in 2 P300 litters. No macroscopic alteration was observed during necropsy.

$P$. incarnata treatment did not influence $(\mathrm{p}>0.05)$ any of the behaviors evaluated in the open-field (Table I) as well as biochemical markers of hepatic function (Table II) and liver weight $(\mathrm{Con}=14.4 \pm 0.4 ; \mathrm{P} 30=13.8 \pm 0.3$, $\mathrm{P} 300=14.7 \pm 1.2$ ).

\section{In vivo evaluation of the antioxidant activity of $P$. incarnata}

Data from the antioxidant/pro-oxidant plasmatic balance in dams are presented in Table III. Two-way ANOVA indicated that $P$. incarnata treatment influenced TRAP levels $[\mathrm{F}(2,42)=5.1, \mathrm{p}<0.05]$. Bonferroni post-hoc test revealed that, compared to CON, P30 tended ( $\mathrm{p}=0.06)$ to increase TRAP and P300 significantly increased it $(\mathrm{p}<0.05)$. Even though total plasmatic antioxidant capacity was increased in P. incarnata-treated dams, a significant difference in the levels of the pro-oxidant markers evaluated (lipid hydroperoxides, MDA, AOPP and NO) was not detected (Two-way ANOVA, $\mathrm{p}>0.05$ ).

\section{In vitro evaluation of the antioxidant activity of $\boldsymbol{P}$. incarnata}

Figure 1A presents the chemiluminescence produced by PMA-stimulated neutrophils in the absence (Control) or presence of 5 and $10 \mu \mathrm{L}$ of $P$. incarnata syrup $(75 \mathrm{mg} /$ $\mathrm{mL}$ ) or vehicle (10 $\mu \mathrm{L}$ of base syrup). Each curve is the mean of 8-10 replicates.

Kruskall-Wallis indicated a significant difference in the peak values of the kinetic curves $(H=30.1, p<0.0001)$. Dunn's test revealed that the peak values obtained with both volumes of $P$. incarnata syrup $(5$ and $10 \mu \mathrm{L})$ were different from control and vehicle (Figure 1B).

TABLE I - Reproductive parameters and general activity in the open-field of dams treated with P. incarnata during gestation and lactation

\begin{tabular}{lccc}
\hline & $\begin{array}{c}\text { Con } \\
(\mathrm{n}=15)\end{array}$ & $\begin{array}{c}\text { P30 } \\
(\mathrm{n}=17)\end{array}$ & $\begin{array}{c}\text { P300 } \\
(\mathrm{n}=14)\end{array}$ \\
\hline REPRODUCTIVE PARAMETERS & & & \\
$\quad$ Live pups (count) & $11.6 \pm 0.4$ & $11.2 \pm 0.9$ & $11.4 \pm 0.6$ \\
$\quad$ Post-implantation loss (\%) & $6.1 \pm 1.9$ & $4.2 \pm 1.8$ & $10.0 \pm 3.8$ \\
$\quad$ Mean pups weight $(\mathrm{g})^{\mathrm{b}}$ & $5.8 \pm 0.1$ & $6.1 \pm 0.2$ & $6.1 \pm 0.2$ \\
GENERAL ACTIVITY & & & \\
Ambulation (count) & $40.9 \pm 2.7$ & $44.0 \pm 2.2$ & $39.9 \pm 2.4$ \\
Rearing (count) & $22.9 \pm 2.0$ & $21.7 \pm 1.5$ & $18.9 \pm 2.3$ \\
Grooming (seconds) & $8.4(5.0-13.9)$ & $8.5(4.2-30.0)$ & $17.4(0.9-40.1)^{\#}$ \\
\hline
\end{tabular}

Except for grooming, data are means \pm SEM and were analyzed by two-way ANOVA (factors: cohort and treatment). Grooming is presented as median (minimum-maximum values) and was analyzed by the non-parametric test of Kruskal-Wallis complemented with Dunn. ${ }^{\#}$ p $<0.05$ compared to P30. Con: distilled water; P30: P. incarnata $30 \mathrm{mg} / \mathrm{kg}$; P300: P. incarnata $300 \mathrm{mg} / \mathrm{kg}$. ${ }^{\mathrm{a}}(\mathrm{Number}$ of uterine implantation sites - number of live fetuses/number of implantations) $x 100 .{ }^{\mathrm{b}}$ Total weight of the litter divided by the total number of the pups on GD 0.

TABLE II - Plasmatic parameters of hepatic function in dams treated with P. incarnata during gestation and lactation

\begin{tabular}{lccc}
\hline & Con & P30 & P300 \\
\hline Total proteins $(\mathrm{g} / \mathrm{dL})$ & $6.0 \pm 0.2(\mathrm{n}=15)$ & $5.8 \pm 0.2(\mathrm{n}=17)$ & $5.8 \pm 0.1(\mathrm{n}=14)$ \\
Albumin $(\mathrm{g} / \mathrm{dL})$ & $2.9 \pm 0.1(\mathrm{n}=15)$ & $3.0 \pm 0.1(\mathrm{n}=16)$ & $3.1 \pm 0.1(\mathrm{n}=13)$ \\
GGT $(\mathrm{IU} / \mathrm{L})$ & $3.3 \pm 0.3(\mathrm{n}=15)$ & $2.6 \pm 0.4(\mathrm{n}=16)$ & $2.5 \pm 0.4(\mathrm{n}=12)$ \\
ALT (IU/L) & $159.6 \pm 6.7(\mathrm{n}=15)$ & $148.8 \pm 7.4(\mathrm{n}=16)$ & $152.2 \pm 10.8(\mathrm{n}=12)$ \\
AST (IU/L) & $140.0(104.0-165.0)(\mathrm{n}=15)$ & $130.0(105.0-215.0)(\mathrm{n}=16)$ & $127.0(110.0-143.0)(\mathrm{n}=12)$ \\
\hline
\end{tabular}

Total proteins, albumin, GGT and ALT are presented as means \pm SEM and were analyzed by two-way ANOVA (p $>0.05)$. AST is presented as median (minimum-maximum) and was analyzed by the non-parametric test of Kruskal-Wallis ( $\mathrm{p}>0.05)$. Con: distilled water; P30: P. incarnata $30 \mathrm{mg} / \mathrm{kg}$; P300: P. incarnata $300 \mathrm{mg} / \mathrm{kg}$. 
TABLE III - Plasmatic oxidative stress parameters in dams treated with $P$. incarnata during gestation and lactation

\begin{tabular}{lccc}
\hline & Con & P30 & P300 \\
\hline $\begin{array}{l}\text { AOPP }(\mu \text { moles/L equivalent of } \\
\text { chloramine })\end{array}$ & $144.9 \pm 9.5(\mathrm{n}=15)$ & $149.7 \pm 9.3(\mathrm{n}=17)$ & $154.1 \pm 10.9(\mathrm{n}=14)$ \\
LOOH $(\mathrm{mM})$ & $0.83 \pm 0.05(\mathrm{n}=15)$ & $0.81 \pm 0.05(\mathrm{n}=17)$ & $0.74 \pm 0.07(\mathrm{n}=14)$ \\
MDA $(\mathrm{ng} / \mathrm{mg}$ of protein) & $69.2 \pm 4.1(\mathrm{n}=13)$ & $76.2 \pm 5.1(\mathrm{n}=15)$ & $75.8 \pm 5.1(\mathrm{n}=13)$ \\
NO $(\mu \mathrm{M} / \mathrm{L})$ & $4.1 \pm 0.8(\mathrm{n}=15)$ & $3.9 \pm 0.5(\mathrm{n}=16)$ & $5.1 \pm 0.7(\mathrm{n}=13)$ \\
TRAP (Trolox equivalents) & $381.4 \pm 12.9(\mathrm{n}=14)$ & $436.4 \pm 16.1^{\&}(\mathrm{n}=15)$ & $450.9 \pm 19.0^{*}(\mathrm{n}=14)$ \\
\hline
\end{tabular}

The results are presented as means \pm SEM. $* \mathrm{p}<0.05$ and ${ }^{\&} \mathrm{p}=0.06$ compared to Con, two-way ANOVA (factors: cohort and treatment) complemented with Bonferroni. Con: distilled water; P30: P. incarnata $30 \mathrm{mg} / \mathrm{kg}$; P300: P. incarnata $300 \mathrm{mg} / \mathrm{kg}$.
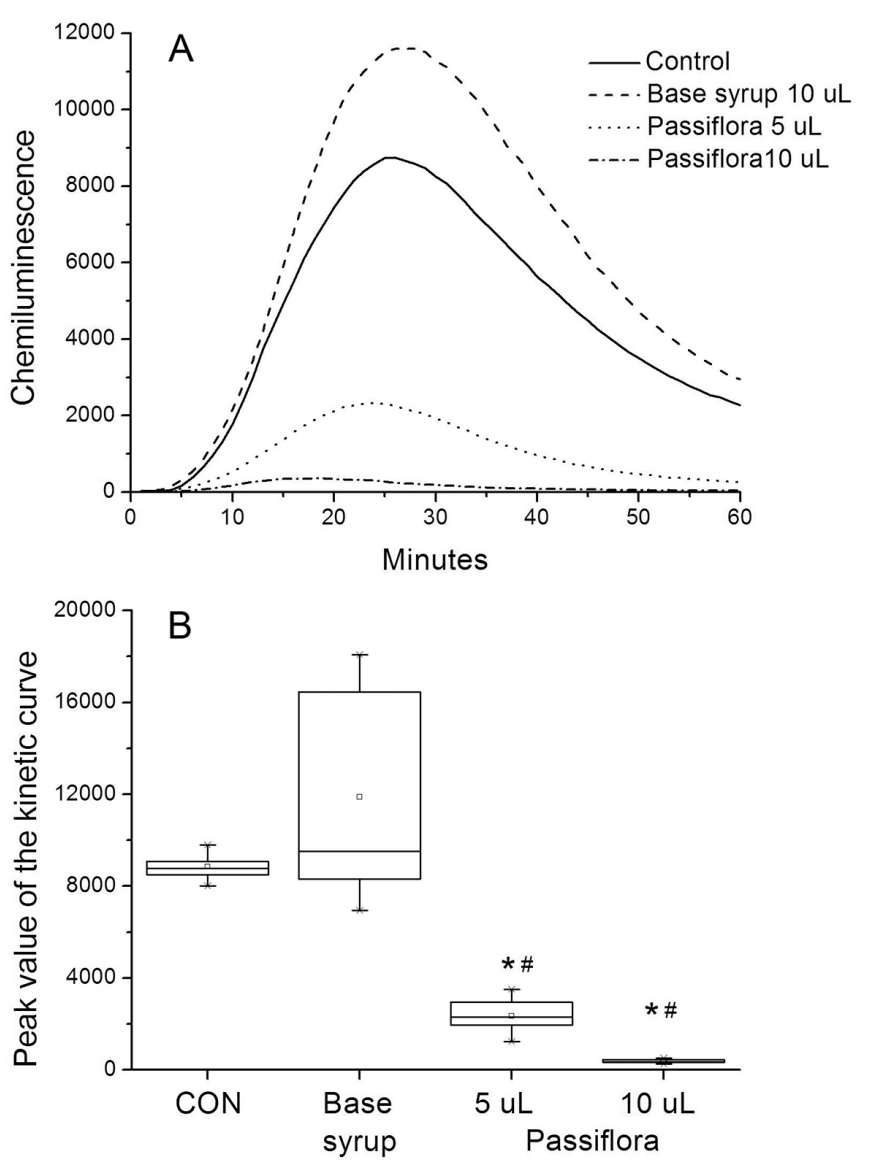

FIGURE 1 - Activation of human neutrophils by PMA in the absence (control) or presence of $P$. incarnata $(5$ or $10 \mu \mathrm{L})$ or base syrup $(10 \mu \mathrm{L})$. Each group was composed by $8-10$ replicates. A. Kinetic curves obtained each other minute for 60 minutes. B. Box plot of the peak values from the kinetic curves. Data were analyzed by Kruskal-Wallis complemented with Dunn's test. * $\mathrm{p}<0.05$ compared to $\mathrm{CON}$; $\# \mathrm{p}<0.05$ compared to base syrup.

\section{DISCUSSION}

In reproductive and developmental toxicity studies, evaluation of maternal toxicity is critical. This study was conducted according to the International Conference on
Harmonization, Technical Requirements for Registration of Pharmaceuticals for Human Use guideline (ICH, 2005). The $P$. incarnata regimen of treatment adopted in the present study did not result in maternal toxicity as evidenced by the lack of effect on parameters of overt general toxicity (clinical signs, weight gain, general activity), hepatic function and reproductive performance. Literature lacks toxicological studies conducted in animals treated repeatedly with $P$. incarnata and none of the available monographs of $P$. incarnata mention results from these types of studies.

In this work, the antioxidant property of $P$. incarnata was evidenced both in vivo and in vitro. In vivo, there was a dose-dependent increase in TRAP which reflects both hydro and lipossoluble antioxidant substances (Repetto et al., 1996). In vitro, there was a decrease in PMA-induced respiratory burst in neutrophils, suggesting a scavenger activity of the syrup. In vitro antioxidant activity has also been described for aqueous and ethanolic extracts of $P$. incarnata in the DPPH (2.2-Diphenyl-1-picrylhydrazide) and ABTS (Azino-bis-(3-ethylbenzthiazoline-6-sulfonic acid) methods (Masteikova et al., 2008). Flavonoids have been described as the main phytoconstituents of P. incarnata (Raffaelli, Moneti, Toja, 1997) and the antioxidant activity of this species has been attributed to these molecules (Masteikova et al., 2008). Flavonoids are phenolic substances that can stabilize and delocalize the unpaired electron within its aromatic ring and are able to reduce free radical formation and to scavenge free radicals. Among the flavonoids that have been described in $P$. incarnata, vicenin, isovitexin and orentin have been shown to play a major role in the in vitro antiradical activity of this species (Masteikova et al., 2008). Moreover, in an in vivo study conducted with Wistar rats gavaged with vitexin and isovitexin, increased total antioxidant capacity has been described (Cao et al., 2011).

Although total plasmatic antioxidant potential was found to be increased in dams treated with $P$. incarnata, it was not observed a significant decrease in the plasmatic markers of oxidation, i.e., lipid hydroperoxides, MDA, 
AOPP and NO. We cannot offer a definitive explanation for this observation but it could be hypothesized that an increased antioxidant capacity could be important to protect macromolecules from oxidation in the presence of oxidative stressors and not at baseline condition. Similar observation, i.e., increased TRAP in normal subjects in the absence of altered levels of lipid hydroperoxides, has also been described in a study from our group designed to evaluate the impact of green tea consumption in normal and dyslipidemic humans (Camargo, Daguer, Barbosa, 2006).

It is interesting to point out that, to our knowledge, this is the first study to describe in vivo antioxidant activity for $P$. incarnata. In the literature, decreased markers of oxidation have been described with other species from the Passiflora genus. P. edulis juice decreased levels of TBARS in the blood (reduced lipid peroxidation) of male rats treated for 28 days with $1,000 \mathrm{mg} / \mathrm{kg}$ of the juice (De Souza et al., 2012). P. alata leaf extract (1 and $5 \mathrm{mg} / \mathrm{kg}$, gavage, 30 days) prevented the increase of hepatic TBARS after a challenge with carbon tetrachloride in male rats (Rudnick et al., 2007).

In conclusion, the results from the present study indicate that $P$. incarnata treatment during gestation and lactation presents antioxidant activity in the absence of maternal reproductive toxicity.

\section{CONFLICTS OF INTEREST STATEMENT}

The authors declare that there are no conflicts of interest.

\section{ACKNOWLEDGEMENTS}

This work was supported by CNPq (fellowship to TZ and LH), Fundação Araucária (fellowship to LFV) and CAPES (fellowship to CCB and ADB).

\section{REFERENCES}

BACCHI, A.D.; PONTE, B.; VIEIRA, M.; DE PAULA, J.C.C.; MESQUITA, S.F.P.; GERARDIN, D.C.C.; MOREIRA, E.G. Developmental exposure to Passiflora incarnata induces behavioral alterations in the male progeny. Reprod. Fertil Dev., v.25, p.782-789, 2013.

BASTOS, A.S.; LOUREIRO, A.P.M.; OLIVEIRA, T.F.; CORBI, S.C.T., CAMINAGA, R.M.S.; ROSSA JR, C.; ORRICO, S.R.P. Quantitation of malondialdehyde in gingival crevicular fluid by a high-performance liquid chromatography-based method. Anal. Biochem., v.423, p.141-146, 2012.
BRASIL. Ministério da Saúde, 2008. Agência Nacional de Vigilância Sanitária. Resolução de Diretoria Colegiada $\mathrm{n}^{\circ}$ 95, de 11 de dezembro de 2008. Regulamenta o texto de bulas de medicamentos fitoterápicos. Available at: http://189.28.128.100/dab/docs/legislacao/ resolucao95_11_12_08.pdf. Accessed on: Sept. 2011.

BUTTAR, H.S.; JONES, K.L. What do we know about the reproductive and developmental risks of herbal and alternate remedies? Birth Defects Res. B Dev. Reprod. Toxicol., v.68, p.492-493, 2003.

CAMARGO, A.; DAGUER, D., BARBOSA, D.S. Green tea exerts antioxidant action in vitro and its consumption increases total serum antioxidant potential in normal and dyslipidemic subjects. Nutr. Res. v.26, p.626-631, 2006.

CAO, D.; LI, H.; JINGJING, Z.; CHE, H.; CAO, J.; YANG, L.; ZHU, C., JIANG, W. Antioxidant properties of the mung bean flavonoids on alleviating heat stress. PLoS One, v.6, E21071, 2011.

DE SOUZA, M.S.S.; BARBALHO, S.M.; DAMASCENO, D.C.; RUDGE, M.V.C.; DE CAMPOS, K.E.; MADI, A.C.G.; COELHO, B.R.; OLIVEIRA, R.C.; DE MELO, R.C.; DONDA, V.C. Effects of Passiflora edulis (yellow passion) on serum lipids and oxidative stress status of Wistar rats. J. Med. Food, v.15, p.78-82, 2012.

FREITAS, M.; PORTO, G.; LIMA, J.L.F.C.; FERNANDES, E. Isolation and activation of human neutrophils in vitro. The importance of the anticoagulant used during blood collection. Clin. Biochem., v.41, p.570-575, 2008.

GRUNDMANN, O.; WANG, J.; McGREGOR, G.P.; BUTTERWECK, V. Anxiolytic activity of a phytochemically characterized Passiflora incarnata extract is mediated via the GABAergic system. Planta Med., v.74, p.1769-1773, 2008.

HUBER, K.; KRÖTZ-FAHNING, M.; HOCK, B. Respiratory burst as a biomarker for stress responses. Protoplasma, v.229, p.221-224, 2006.

INTERNATIONAL CONFERENCE ON HARMONIZATION. ICH. Technical Requirements for Registration of Pharmaceuticals for Human Use, 2005. Detection of toxicity to reproduction for medicinal products \& toxicity to male fertility S5(R2). Available at: http://www.ich.org/products/ guidelines/safety/safety-single/article/detection-of-toxicityto-reproduction-for-medicinal-products-toxicity-to-malefertility.html. Accessed on: 27/02/2014. 
JIANG, Z.Y.; WOOLLARD, A.C.S.; WOLFF, S.P. Lipid hydroperoxide measurement by oxidation of $\mathrm{Fe}^{2+}$ in the presence of xylenol orange. Comparison with the TBA assay and the iodometric method. Lipids, v.26, p.853-856, 1991.

KOREN, G.; DUGOUA, J.J.; MAGEE, L.; VOHRA, S.; MATSUI, D.; BÉRARD, A.; JOHNSON, B.; MORETTI, M.; EINARSON, A. Mother Nature: establishing a Canadian research network for natural health products (NHPs) during pregnancy and lactation. J. Altern. Complement. Med., v.14, p.369-372, 2008.

MASTEIKOVA, R.; BERNATONIENE, J.; BERNATONIENE, R.; VELZIENE, S. Antiradical activities of the extract of Passiflora incarnata. Acta Pol. Pharm., v.65, p.577-583, 2008.

NAVARRO-GONZÁLVEZ, J.A.; GARCIA-BENAYAS, C.; ARENAS, J. Semiautomated measurement of nitrate in biological fluids. Clin. Chem., v.44, p.679-681, 1998.

RAFFAELLI, A.; MONETI, G.; TOJA, E. Mass spectrometric characterization of flavonoids in extracts from Passiflora incarnata. J. Chromatogr., v.777, p.223-231, 1997.

REPETTO, M.; REIDES, C.; CARRETERO, M.L.G.; COSTA, M.; GRIEMBERG, G.; LLESUY, S. Oxidative stress in blood of HIV infected patients. Clin. Chim. Acta, v.255, p.107-117, 1996.

RUDNICKI, M.; SILVEIRA, M.M.; PEREIRA, T.V.; OLIVEIRA, M.R.; REGINATTO, F.H.; DAL-PIZZOL, F.; MOREIRA, J.C.F. Protective effects of Passiflora alata extract pretreatment on carbon tetrachloride induced oxidative damage in rats. Food Chem. Toxicol., v.45, p.656$661,2007$.
RUGGY, G.H.; SMITH, C.S. A pharmacological study of the active principle of Passiflora incarnata. J. Am. Pharm. Assoc., v.29, p.245-249, 1940.

SOULIMANI, R.; YOUNOS, C.; JARMOUNI, S.; BOUSTA, D.; MISSLIN, R.; MORTIER, F. Behavioral effects of $P$. incarnata $L$. and its indole alkaloid and flavonoid derivatives and maltol in the mouse. J. Ethnopharmacol., v.57, p.11-20, 1997.

VERÍSSIMO, L.F.; BACCHI, A.D.; ZAMINELLI, T.; DE PAULA, G.H.O.; MOREIRA, E.G. Herbs of interest to the Brazilian Federal Government: female reproductive and developmental toxicity studies. Rev. Bras. Farmacogn., v.21, p.1163-1171, 2011.

WITKO-SARSAT, V.; FRIEDLANDER, M.; KHOA, T.N.; CAPEEILLÈRE-BLANDIN, C.; NGUYEN, A.T.; CANTELOUP, S.; DAYER, J.M.; JUNGERS, P.; DRÜEKE, T.; DESCHAMPS-LATSCHA, B. Advanced oxidation protein products as novel mediators of inflammation and monocyte activation in chronic renal failure. J. Immunol., v.161, p.2524-2532, 1998.

YUNES, R.A.; CALIXTO, J.B. Plantas medicinais: sob a ótica da química medicinal moderna. 1.ed. Chapecó: Argos Editora Universitária, 2001. 523 p.

ZANOLI, P.; AVALLONE, R.; BARALDI, M. Behavioral characterization of the flavonoids apigenin and chrysin. Fitoterapia, v.71, p.117-123, 2000.

Received for publication on $17^{\text {th }}$ July 2013 Accepted for publication on $16^{\text {th }}$ September 2013 
